\title{
Backbone and partial side chain assignment of the microtubule binding domain of the MAP1B light chain
}

\author{
Zsuzsanna Orbán-Németh • Morkos A. Henen • Leonhard Geist • \\ Szymon Żerko • Saurabh Saxena · Jan Stanek - Wiktor Koźmiński • \\ Friedrich Propst $\cdot$ Robert Konrat
}

Received: 21 November 2012/ Accepted: 12 January 2013/Published online: 22 January 2013

(C) The Author(s) 2013. This article is published with open access at Springerlink.com

\begin{abstract}
Microtubule-associated protein 1B (MAP1B) is a classical high molecular mass microtubule-associated protein expressed at high levels in the brain. It confers specific properties to neuronal microtubules and is essential for neuronal differentiation, brain development and synapse maturation. Misexpression of the protein contributes to the development of brain disorders in humans. However, despite numerous reports demonstrating the importance of MAP1B in regulation of the neuronal cytoskeleton during neurite extension and axon guidance, its mechanism of action is still elusive. Here we focus on the intrinsically disordered microtubule binding domain of the light chain of MAP1B. In order to obtain more detailed structural information about this domain we assigned NMR chemical shifts of backbone and aliphatic side chain atoms.
\end{abstract}

Keywords Microtubule-associated protein - Microtubule binding domain · Random sampling · Intrinsically disordered protein

Z. Orbán-Németh $\cdot$ F. Propst $(\bowtie)$

Department of Biochemistry and Cell Biology, Max F. Perutz Laboratories, University of Vienna, Vienna Biocenter Campus 1, 1030 Vienna, Austria

e-mail: friedrich.propst@univie.ac.at

M. A. Henen · L. Geist · R. Konrat ( $₫)$

Department of Structural and Computational Biology, Max F. Perutz Laboratories, University of Vienna, Vienna Biocenter Campus 5, 1030 Vienna, Austria

e-mail: robert.konrat@univie.ac.at

S. Żerko · S. Saxena · J. Stanek · W. Koźmiński Faculty of Chemistry, University of Warsaw, Pasteura 1, 02-093 Warsaw, Poland

\section{Biological context}

During development and repair of the nervous system, individual neurons extend long processes to connect to each other to build or restore a network capable of information processing. Elaboration of these processes, axons and dendrites, crucially depends on microtubules, one component of the neuronal cytoskeleton. The dynamic behavior, the stability and the properties of microtubules are temporarily and spatially regulated by a plethora of microtubule-associated proteins (MAPs). Among these are the 3 members of the MAP1 family of proteins, MAP1A, MAP1B and MAP1S. All three are protein complexes consisting of heavy and light chains and share isolated domains of sequence homology (Schoenfeld et al. 1989; Orban-Nemeth et al. 2005).

The best characterized of these proteins is MAP1B, a large neuronal protein essential for neuronal network formation during murine brain development (Edelmann et al. 1996; Takei et al. 1997; Gonzalez-Billault et al. 2000; Meixner et al. 2000) and for the maturation of synapses (Tortosa et al. 2011). Overexpression or deregulation of MAP1B activity have been associated with fragile $X$ mental retardation (Brown et al. 2001; Zhang et al. 2001), giant axonal neuropathy (Allen et al. 2005), and ataxia (Opal et al. 2003) in humans.

The MAP1B protein complex consists of a $300-\mathrm{kDa}$ heavy chain and at least one light chain termed LC1. The light chain is around 250 amino acids ( $32 \mathrm{kDa})$ in size and has several important functional domains. Via its $\mathrm{NH}_{2}-$ terminal domain it is capable of interacting with and changing the conformation of microtubules (Tögel et al. 1998). The light chains of MAP1A and MAP1S contain a functionally related microtubule binding domain in their respective $\mathrm{NH}_{2}$ termini; however, there is no sequence 
homology. In contrast, the COOH-terminal half of the MAP1B light chain is conserved in function as well as sequence among all MAP1 proteins. Via this part of the molecule the light chains can interact with actin filaments and with the heavy chains for the formation of the respective MAP1 protein complex (Tögel et al. 1998; Noiges et al. 2002, 2006; Orban-Nemeth et al. 2005). The interaction of the MAP1B light chain with microtubules can be regulated by posttranslational modification, in particular S-nitrosylation, at an identified cysteine residue in its $\mathrm{COOH}$ terminus (Stroissnigg et al. 2007). Being able to bind to microtubules as well as F-actin, MAP1B is considered to be a coupling protein between the two components of the neuronal cytoskeleton (Bouquet et al. 2007). Such proteins are postulated to be essential for orchestrated regulation of the cytoskeleton during neuronal differentiation (Lowery and Van Vactor 2009). However, despite the fact that MAP1B has been discovered many years ago and despite its demonstrated involvement in human disease a clear understanding of its function is still missing.

Meta structure analysis of the MAP1B light chain suggests that the positively charged $\mathrm{NH}_{2}$-terminal microtubule binding domain is intrinsically disordered, whereas the conserved $\mathrm{COOH}$ terminus is predicted to be structured. To obtain further insight into how this protein can modulate microtubule properties we initiated NMR structure determination of the $\mathrm{NH}_{2}$-terminal microtubule binding domain. This analysis might eventually also shed light on specific functions of microtubules during neuronal differentiation. Here we report near complete backbone assignment as well as partial assignment of aliphatic side chain atoms, using sophisticated 5D triple resonance NMR experiments.

\section{Methods and experiments}

Expression and purification of the $\mathrm{NH}_{2}$ terminus of the MAP1B light chain

A cDNA fragment encoding the $\mathrm{NH}_{2}$-terminal domain of the rat MAP1B light chain (amino acids 2212-2338, NP_062090.1) was cloned into a pET-15b (Novagen) derived expression vector. The resulting plasmid, pMA25His, encodes the microtubule binding domain of the MAP1B light chain fused to an $\mathrm{NH}_{2}$-terminal tag containing 6 histidines (MGSSHHHHHHSSGLVPRGSHMEF). The sequence was confirmed to be correct. pMA25His plasmid was introduced into BL21Codon Plus(DE3) cells (Stratagene) by heat shock at $42{ }^{\circ} \mathrm{C}$ for $90 \mathrm{~s}$. Cells were grown overnight in LB medium at $37{ }^{\circ} \mathrm{C}$ supplemented with $50 \mu \mathrm{g} / \mathrm{ml}$ ampicillin and $25 \mu \mathrm{g} / \mathrm{ml}$ chloramphenicol. This culture was diluted 1:40 in $21 \mathrm{LB}$ with antibiotics and was incubated at $37{ }^{\circ} \mathrm{C}$ until the culture reached an $\mathrm{OD}_{600}$ of 0.7 . Cells were collected at 5,000 rpm for $12 \mathrm{~min}$ and resuspended in half the volume of modified M9 minimal medium (Marley et al. 2001) supplemented with $1 \mathrm{~g}$ of ${ }^{15} \mathrm{NH}_{4} \mathrm{Cl}$ and $2 \mathrm{~g}$ of $\mathrm{D}-\left[{ }^{13} \mathrm{C}\right]$ glucose (Cambridge Isotope Laboratories) and trace elements instead of basal vitamins. Cells were incubated for one additional hour at $37^{\circ} \mathrm{C}$. Recombinant

Table 1 Maximum evolution times (tmax, ms) and spectral width (sw, kHz) used for acquisition of spectra for the $\mathrm{NH}_{2}$ terminus of the light chain of MAP1B

\begin{tabular}{|c|c|c|c|c|c|c|c|}
\hline & $\begin{array}{l}\text { 3D } \\
\text { HNCO }\end{array}$ & $\begin{array}{l}\text { 4D } \\
\text { HNCACO }\end{array}$ & $\begin{array}{l}\text { 5D } \\
\mathrm{HabCabCONH}\end{array}$ & $\begin{array}{l}\text { 5D } \\
\mathrm{HN}(\mathrm{CA}) \mathrm{CONH}\end{array}$ & $\begin{array}{l}5 \mathrm{D} \\
\mathrm{H}(\mathrm{CC}- \\
\text { tocsy)CONH }\end{array}$ & $\begin{array}{l}5 \mathrm{D} \\
(\mathrm{H}) \mathrm{NCO}(\mathrm{NCA}) \mathrm{CONH}\end{array}$ & $\begin{array}{l}\text { 5D } \\
(\mathrm{HACA}) \mathrm{CON}(\mathrm{CA}) \\
\mathrm{CONH}\end{array}$ \\
\hline $\begin{array}{l}\text { Number of } \\
\text { points }\end{array}$ & 750 & 1800 & 715 & 780 & 1285 & 700 & 900 \\
\hline $\begin{array}{l}\text { Experiment } \\
\text { duration (h) }\end{array}$ & 5 & 23 & 18 & 20 & 42 & 18 & 19 \\
\hline $\mathrm{sw}_{1}$ & 2.8 & 2.8 & 4 & 6 & 8 & 2.5 & 3.8 \\
\hline $\mathrm{sw}_{2}$ & 2.5 & 6.2 & 14 & 2.5 & 18 & 2.8 & 2.8 \\
\hline $\mathrm{sw}_{3}$ & & 2.5 & 2.8 & 2.8 & 2.8 & 2.8 & 2.8 \\
\hline $\mathrm{sw}_{4}$ & & & 2.5 & 2.5 & 2.5 & 2.5 & 2.5 \\
\hline$t_{1}^{\max }$ & 100 & 50 & 15 & 20 & 15 & 30 & 30 \\
\hline$t_{2}^{\max }$ & 100 & 10 & 7 & 50 & 8 & 30 & 30 \\
\hline$t_{3}^{\max }$ & & 75 & 30 & 50 & 30 & 30 & 30 \\
\hline$t_{4}^{\max }$ & & & 50 & 50 & 50 & 50 & 50 \\
\hline $\begin{array}{l}\text { Sampling } \\
\text { density versus } \\
\text { conventional }\end{array}$ & $1.1 \times 10^{-2}$ & $1.1 \times 10^{-3}$ & $1.2 \times 10^{-5}$ & $3.0 \times 10^{-6}$ & $7.1 \times 10^{-6}$ & $1.1 \times 10^{-5}$ & $9.0 \times 10^{-6}$ \\
\hline
\end{tabular}


protein synthesis was induced by the addition of isopropyl$\beta$-d-thiogalactopyranoside (IPTG) to a final concentration of $0.5 \mathrm{mM}$, and incubation was continued overnight at $18{ }^{\circ} \mathrm{C}$. The cells were collected by centrifugation at 4,000 rpm for $15 \mathrm{~min}$ and resuspended in $10 \mathrm{ml}$ of ice-cold lysis buffer $\left(50 \mathrm{mM} \mathrm{NaH} \mathrm{PO}_{4}, 300 \mathrm{mM} \mathrm{NaCl}, \mathrm{pH}\right.$ 8). Cells were lysed by sonication at $80 \%$ for $20 \times 10 \mathrm{~s}$ in $10 \mathrm{ml}$ lysis buffer containing $40 \mathrm{mg}$ lysozyme, $1 \mathrm{mg}$ DNase I, and 4 EDTA free complete mini protease inhibitor tablets (Roche). The lysate was cleared by centrifugation at $13,000 \mathrm{rpm}$ for $30 \mathrm{~min}$. The supernatant was loaded onto an FPLC $\mathrm{Ni}^{2+}$-loaded HisTrap FF crude $5 \mathrm{ml}$ affinity column (GE Healthcare). The column was washed with lysis buffer containing $20 \mathrm{mM}$ imidazole. The recombinant protein was eluted with lysis buffer containing $75 \mathrm{mM}$ imidazole, concentrated approximately 10 -fold by centrifugation through an Amicon Ultra-15 centrifugal $3 \mathrm{~K}$ filter device and loaded onto a Superdex 200 HiLoad 16/60 prep grade gel filtration column (GE Healthcare) equilibrated in lysis buffer. The final yield of homogenous recombinant protein was approximately $2 \mathrm{mg} / \mathrm{l}$ of bacterial culture. For NMR analysis, protein samples were concentrated to at least $700 \mu \mathrm{M}$ and $\mathrm{pH}$ was changed to 5 .

\section{NMR experiments}

All spectra were acquired at $298 \mathrm{~K}$ on an Agilent Direct Drive $700 \mathrm{MHz}$ spectrometer using the standard $5 \mathrm{~mm}$ ${ }^{1} \mathrm{H}-{ }^{13} \mathrm{C}-{ }^{15} \mathrm{~N}$ triple-resonance probehead.

The backbone ${ }^{1} \mathrm{H},{ }^{13} \mathrm{C}$ and ${ }^{15} \mathrm{~N}$ resonances were assigned using sparse random sampling of indirectly detected time domains, in order to increase resolution. A 3D HNCO experiment was used as a base spectrum for SMFT (Sparse Multidimensional Fourier Transform) processing of higher dimensionality experiments (Kazimierczuk et al. 2009). Backbone assignment was achieved using 5D HN(CA)CONH (Kazimierczuk et al. 2010), (HACA)CON (CA)CONH (Zawadzka-Kazimierczuk et al. 2012b), (H)NCO(NCA)CONH (Zawadzka-Kazimierczuk et al. 2012b) and 4D HNCACO (Zawadzka-Kazimierczuk et al. 2010) experiments. Side-chain assignments were obtained using 5D HabCabCONH (Kazimierczuk et al. 2010), and H(CC-tocsy)CONH (Kazimierczuk et al. 2009) experiments.

All NMR data sets were processed by multidimensional Fourier transformation using the home written software package (http://nmr700.chem.uw.edu.pl/formularz.html). The resonance assignment was performed using the TSAR program (Zawadzka-Kazimierczuk et al. 2012a). The input data for TSAR was prepared and analyzed using the Sparky software (Goddard and Kneller 2008). Table 1 shows the maximum evolution times and spectral width used for the acquisition of the spectra.

\section{Assignments and data deposition}

The ${ }^{1} \mathrm{H}_{-}{ }^{15} \mathrm{~N}$ HSQC spectrum of the $\mathrm{NH}_{2}$ terminus of the light chain of MAP1B shows the for intrinsically disordered proteins typical narrow peak dispersion in the ${ }^{1} \mathrm{H}$ dimension (Fig. 1). The use of the aforementioned 5D experiments allowed us to nearly completely assign backbone atoms by resolving extensively overlapping signals in conventional 2D and 3D spectra. $89 \%$ of backbone ${ }^{15} \mathrm{~N}$, $95.8 \%$ of ${ }^{1} \mathrm{H}^{\mathrm{N}}, 88.2 \%$ of ${ }^{13} \mathrm{C}^{\alpha}, 88.2 \%$ of ${ }^{1} \mathrm{H}^{\alpha}$ and $88.2 \%$ of ${ }^{13} \mathrm{C}^{\mathrm{O}}$ resonances could be assigned (calculated without His-tag). Additionally, HabCabCONH and H(CC-tocsy)CONH spectra allowed the assignment of several aliphatic side chain atoms. $87.4 \%$ of ${ }^{13} \mathrm{C}^{\beta}, 87.4 \%$ of ${ }^{1} \mathrm{H}^{\beta}$, $79.2 \%$ of ${ }^{13} \mathrm{C}^{\gamma}, 85.2 \%$ of ${ }^{1} \mathrm{H}^{\gamma}, 51.6 \%{ }^{13} \mathrm{C}^{\delta}$ and $62.7 \%$ of ${ }^{1} \mathrm{H}^{\delta}$ could be assigned. For 7 out of 29 lysine side chains we also obtained the ${ }^{13} \mathrm{C}^{\varepsilon}$ and ${ }^{1} \mathrm{H}^{\varepsilon}$ assignments. Figure 2 outlines sequential resonance assignment in a $5 \mathrm{D}(\mathrm{H}) \mathrm{NCO}$

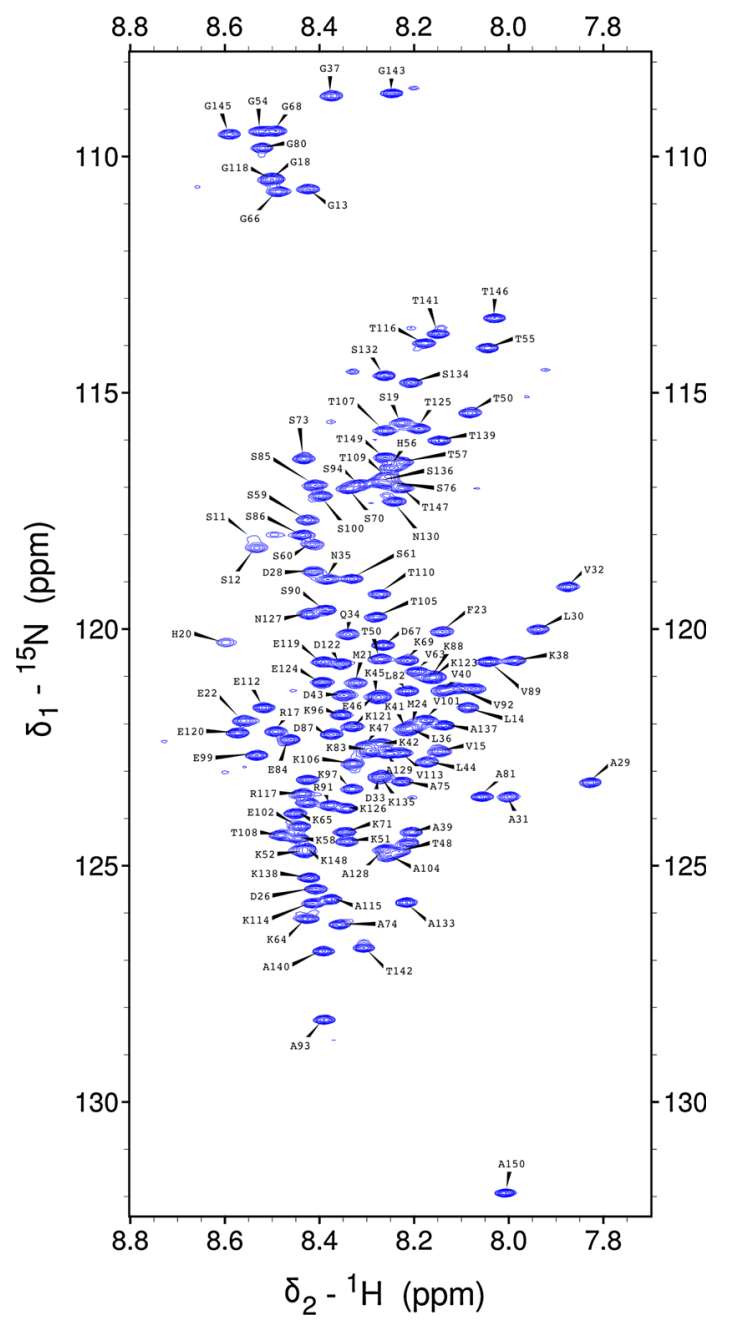

Fig. $1{ }^{1} \mathrm{H}-{ }^{15} \mathrm{~N}$ HSQC spectrum of the $\mathrm{NH}_{2}$ terminus of the light chain of MAP1B at pH5 and $298 \mathrm{~K}$. Assignments of backbone amides are labeled in single letter amino acid code and residue number (His6tag: 1-23; $\mathrm{NH}_{2}$ terminus of the light chain of MAP1B: 24-150) 


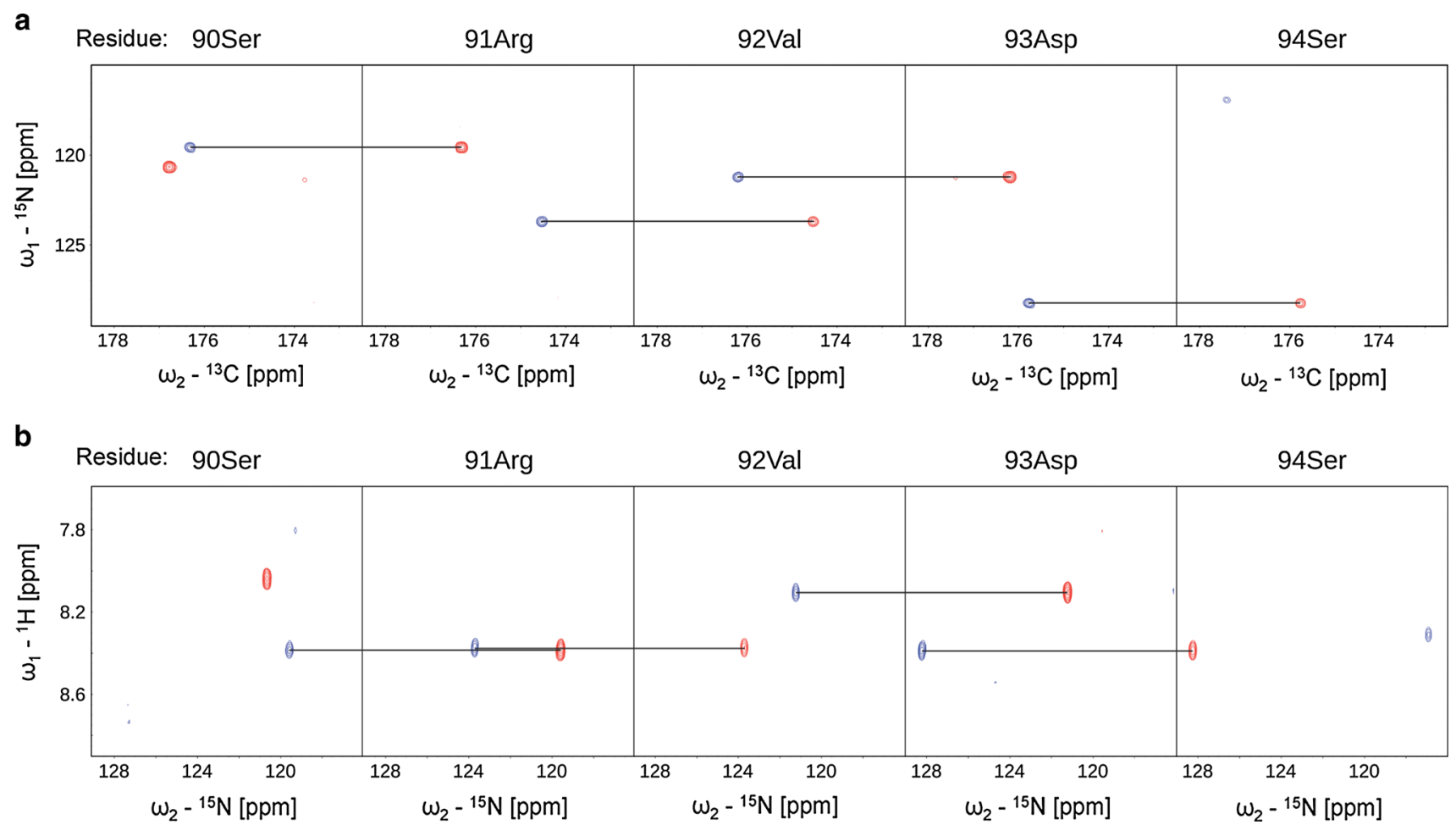

Fig. 2 2D spectral planes for consecutive amino acids in the $\mathrm{NH}_{2}$ terminus of the light chain of MAP1B obtained by SMFT processing of the 5D randomly sampled signal. 2D cross-sections of a $5 \mathrm{D}(\mathrm{H}) \mathrm{NCO}(\mathrm{NCA}) \mathrm{CONH}\left(\mathrm{N}_{\mathrm{i}}-\mathrm{CO}_{\mathrm{i}-1}\right.$ and $\left.\mathrm{N}_{\mathrm{i}-1}-\mathrm{CO}_{\mathrm{i}-2}\right)$ and b $5 \mathrm{D} \mathrm{HN}(\mathrm{CA}) \mathrm{CONH}\left(\mathrm{HN} \mathrm{N}_{\mathrm{i}}-\mathrm{N}_{\mathrm{i}}\right.$ and $\left.\mathrm{HN}_{\mathrm{i}+1}-\mathrm{N}_{\mathrm{i}+1}\right)$

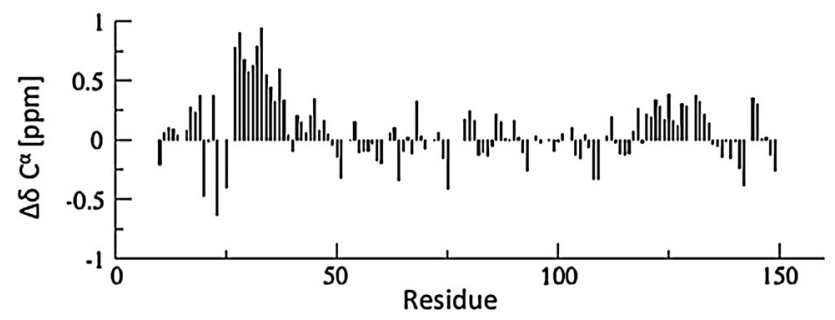

Fig. 3 Graph showing ${ }^{13} \mathrm{C}^{\alpha}$ secondary chemical shifts of the $\mathrm{NH}_{2}$ terminus of the light chain of MAP1B. Random coil chemical shift values were obtained using the neighborhood-corrected IDP chemical shift library (Tamiola et al. 2010)

(NCA)CONH and $\mathrm{HN}(\mathrm{CA}) \mathrm{CONH}$ experiment, showing strips of sequential residues. Secondary chemical shifts for ${ }^{13} \mathrm{C}^{\alpha}$ (Fig. 3) show only minor deviations from random coil chemical shift values with slight $\alpha$-helical propensities at the $\mathrm{NH}_{2}$ terminus, corroborating the finding of the Meta Structure analysis (not shown).

The ${ }^{1} \mathrm{H},{ }^{13} \mathrm{C}$ and ${ }^{15} \mathrm{~N}$ chemical shift assignments have been deposited in the BioMagResBank database (http://www. bmrb.wisc.edu) under the accession number 18895.

Acknowledgments NMR experiments were carried out in the Structural Research Laboratory at the Faculty of Chemistry, University of Warsaw. This work was supported by the Bio-NMR Project No. 261863 funded by European Commissions Framework Program 7
(FP7). S.S., S.Ż. and W.K. thank the Foundation for Polish Science for the support with the TEAM Programme, co-financed by the European Union within the European Regional Development Fund. This research was also supported by grant P20839-B09 (to F.P.) from the Austrian Science Fund (FWF) and ÖAD (Ku with Egypt, art 9/2) (to M.A.H).

Open Access This article is distributed under the terms of the Creative Commons Attribution License which permits any use, distribution, and reproduction in any medium, provided the original author(s) and the source are credited.

\section{References}

Allen E, Ding J, Wang W, Pramanik S, Chou J, Yau V, Yang Y (2005) Gigaxonin-controlled degradation of MAP1B light chain is critical to neuronal survival. Nature 438(7065):224-228

Bouquet C, Ravaille-Veron M, Propst F, Nothias F (2007) MAP1B coordinates microtubule and actin filament remodeling in adult mouse Schwann cell tips and DRG neuron growth cones. Mol Cell Neurosci 36(2):235-247

Brown V, Jin P, Ceman S, Darnell JC, O’Donnell WT, Tenenbaum SA, Jin X, Feng Y, Wilkinson KD, Keene JD, Darnell RB, Warren ST (2001) Microarray identification of FMRP-associated brain mRNAs and altered mRNA translational profiles in fragile X syndrome. Cell 107(4):477-487

Edelmann W, Zervas M, Costello P, Roback L, Fischer I, Hammarback JA, Cowan N, Davies P, Wainer B, Kucherlapati R (1996) Neuronal abnormalities in microtubule-associated protein $1 \mathrm{~B}$ mutant mice. Proc Natl Acad Sci USA 93:1270-1275 
Goddard TD, Kneller DG (2008) SPARKY 3. University of California, San Francisco

Gonzalez-Billault C, Demandt E, Wandosell F, Torres M, Bonaldo P, Stoykova A, Chowdhury K, Gruss P, Avila J, Sánchez MP (2000) Perinatal lethality of microtubule-associated protein 1Bdeficient mice expressing alternative isoforms of the protein at low levels. Mol Cell Neurosci 16(4):408-421

Kazimierczuk K, Zawadzka A, Kozminski W (2009) Narrow peaks and high dimensionalities: exploiting the advantages of random sampling. J Magn Reson 197(2):219-228. doi:10.1016/j.jmr. 2009.01.003

Kazimierczuk K, Zawadzka-Kazimierczuk A, Kozminski W (2010) Non-uniform frequency domain for optimal exploitation of nonuniform sampling. J Magn Reson 205(2):286-292. doi:10.1016/j. jmr.2010.05.012

Lowery LA, Van Vactor D (2009) The trip of the tip: understanding the growth cone machinery. Nat Rev Mol Cell Biol 10(5): 332-343. doi:10.1038/nrm2679

Marley J, Lu M, Bracken C (2001) A method for efficient isotopic labeling of recombinant proteins. J Biomol NMR 20(1): $71-75$

Meixner A, Haverkamp S, Wässle H, Führer S, Thalhammer J, Kropf N, Bittner RE, Lassmann H, Wiche G, Propst F (2000) MAP1B is required for axon guidance and is involved in the development of the central and peripheral nervous system. J Cell Biol 151:1169-1178

Noiges R, Eichinger R, Kutschera W, Fischer I, Németh Z, Wiche G, Propst F (2002) MAP1A and MAP1B: light chains determine distinct functional properties. J Neurosci 22(6):2106-2114

Noiges R, Stroissnigg H, Trancikova A, Kalny I, Eichinger R, Propst F (2006) Heterotypic complex formation between subunits of microtubule-associated proteins $1 \mathrm{~A}$ and $1 \mathrm{~B}$ is due to interaction of conserved domains. Biochim Biophys Acta 1763(10): $1011-1016$

Opal P, Garcia JJ, Propst F, Matilla A, Orr HT, Zoghbi HY (2003) Mapmodulin/leucine-rich acidic nuclear protein binds the light chain of microtubule-associated protein $1 \mathrm{~B}$ and modulates neuritogenesis. J Biol Chem 278(36):34691-34699

Orban-Nemeth Z, Simader H, Badurek S, Trancikova A, Propst F (2005) Microtubule-associated protein 1S, a short and ubiquitously expressed member of the microtubule-associated protein 1 family. J Biol Chem 280(3):2257-2265
Schoenfeld TA, McKerracher L, Obar R, Vallee RB (1989) MAP 1A and MAP $1 \mathrm{~B}$ are structurally related microtubule associated proteins with distinct developmental patterns in the CNS. J Neurosci 9:1712-1730

Stroissnigg H, Trančíková A, Descovich L, Fuhrmann J, Kutschera W, Kostan J, Meixner A, Nothias F, Propst F (2007) S-nitrosylation of microtubule-associated protein $1 \mathrm{~B}$ mediates nitric oxide induced axon retraction. Nat Cell Biol 9(9):1035-1045

Takei Y, Kondo S, Harada A, Inomata S, Noda T, Hirokawa N (1997) Delayed development of nervous system in mice homozygous for disrupted microtubule-associated protein 1B (MAP1B) gene. J Cell Biol 137:1615-1626

Tamiola K, Acar B, Mulder FA (2010) Sequence-specific random coil chemical shifts of intrinsically disordered proteins. J Am Chem Soc 132(51):18000-18003. doi:10.1021/ja105656t

Tögel M, Wiche G, Propst F (1998) Novel features of the light chain of microtubule-associated protein MAP1B: microtubule stabilization, self interaction, actin filament binding, and regulation by the heavy chain. J Cell Biol 143(3):695-707

Tortosa E, Montenegro-Venegas C, Benoist M, Hartel S, GonzalezBillault C, Esteban JA, Avila J (2011) Microtubule-associated protein 1B (MAP1B) is required for dendritic spine development and synaptic maturation. J Biol Chem 286(47):40638-40648. doi:10.1074/jbc.M111.271320

Zawadzka-Kazimierczuk A, Kazimierczuk K, Kozminski W (2010) A set of 4D NMR experiments of enhanced resolution for easy resonance assignment in proteins. J Magn Reson 202(1): 109-116. doi:10.1016/j.jmr.2009.10.006

Zawadzka-Kazimierczuk A, Kozminski W, Billeter M (2012a) TSAR: a program for automatic resonance assignment using 2D cross-sections of high dimensionality, high-resolution spectra. J Biomol NMR 54(1):81-95. doi:10.1007/s10858-0129652-3

Zawadzka-Kazimierczuk A, Kozminski W, Sanderova H, Krasny L (2012b) High dimensional and high resolution pulse sequences for backbone resonance assignment of intrinsically disordered proteins. J Biomol NMR 52(4):329-337. doi:10.1007/s10858012-9613-x

Zhang YQ, Bailey AM, Matthies HJ, Renden RB, Smith MA, Speese SD, Rubin GM, Broadie K (2001) Drosophila fragile X-related gene regulates the MAP1B homolog Futsch to control synaptic structure and function. Cell 107(5):591-603 